\title{
"Challenging Containment: African Americans and Racial Politics in Montclair, New Jersey, 1920-1940"
}

\author{
Patricia Hampson Eget
}

In 1930 Mary Elizabeth Bolden sent for her ten year old son, Theodore, from the rural Virginia farm where the family worked as sharecroppers. She had moved to Montclair the previous year with her sister, Ada, and brother in-law, James, and worked as a domestic servant to support herself. Montclair offered Theodore tremendous educational opportunities. He attended Nishuane Grammar School, Glenfield Junior High School, and Montclair High School. Black residents encouraged Theodore to attend college even though no one in his family had more than a high school education and he had no money for college. LaVerte Warren, a local physician, convinced Theodore to take college preparatory rather than vocational courses at Montclair High School when he visited Theodore's home to administer medicine for the flu. After learning that Theodore was enrolled in vocational courses, Dr. Warren insisted that Theodore reconsider taking college preparatory courses, informing him that, "if you learn typing and bookkeeping and the opportunity comes to go to college, you won't be able to." Theodore immediately switched. After he finished high school, the Women's Educational Club, a local Black women's club, provided a scholarship that allowed him to attended Lincoln University and become a dentist. In 1977, he was appointed dean of New Jersey Dental School, the first Black dean of a predominantly white dental school in the United States. He credited Montclair's Black community for his educational advancement, declaring that, "I went to college because of Dr. Warren.",

Theodore's ascent into the black professional class exemplifies the economic and social advancement of Montclair's black community from the 1920s into the 1940s and beyond. According to the Townswomen of Montclair, a Black women's club, African Americans migrated to Montclair primarily from Loudon and Fahquier Counties in Northern Virginia during the early twentieth century to work in service sector jobs. ${ }^{3}$ While these jobs offered higher wages than the jobs many migrants had previously held as sharecroppers, blacks became financially dependent on Montclair's white middle and upper class residents who exploited this unequal economic relationship to create a complex racial hierarchy that rested on the civic, social, geographic and economic containment and subordination of African Americans.

Scholars have equated movement from service sector into blue-collar industrial jobs with economic mobility for African Americans in cities the Northeast and Midwest. In Montclair, however, African Americans more often advanced from service sector into white-collar and

\footnotetext{
1 Theodore Bolden Interview. Interviewed by Elizabeth Sheppard on April 2, 2001. Montclair Historical Society. Montclair, New Jersey.

2 Theodore Bolden Interview. Interviewed by Elizabeth Sheppard on April 2, 2001. Montclair Historical Society. Montclair, New Jersey.

${ }^{3}$ Our Town and the Old Townsmen of Montclair. (Montclair, N.J.: Townswomen of Montclair, 1952).

Privately Published. Montclair Historical Society. Montclair, New Jersey.
} 
professional jobs. ${ }^{4}$ Additionally, Darlene Clark Hine argues that the African American professional class created institutions and networks they later mobilized against racial discrimination. My work on interwar Montclair, however, complicates this argument, identifying that people who worked as maids, cooks, and janitors were also at the forefront of the struggle for equality. The Black community's economic and educational advances during interwar period and beyond established economic independence. Since their social and political containment was linked to their economic dependency, African Americans' economic advancement challenged Montclair's racial hierarchy. ${ }^{5}$

Andrew Wiese and Leslie Wilson have sketched a national history of African American suburbanization during the twentieth century, demonstrating that black suburbanites moved to the suburbs for educational and economic opportunities, more rural environments, and the promise of social and political autonomy. ${ }^{6}$ Walter Greason, Karyn Lacy, Robert Lake, Valerie Johnson, and Bruce Haynes have examined middle-class African American suburbanization in the post Civil Rights Movement era, emphasizing that predominantly Black, middle-class suburbs continued to have unequal access to school, police protection, and other government services. ${ }^{7}$ Nevertheless, these scholars argue that middle-class black suburbanites display enormous pride in the suburban identity of their communities.

This article examines Montclair as an example of racial politics in an interracial service suburb during the early twentieth century, a topic that needs more attention from scholars. In 1939, Edward Lee Thorndike, a social scientist at Columbia University, identified affluent, predominantly white, residential suburbs as the most desirable communities in the entire country in his attempt to rank the "goodness" of life in communities across the U.S. Alongside of Montclair, Glendale, Berkeley, and Pasadena, California, Evanston, Illinois, Oak Park, Illinois, Brookline, MA, White Plains, New York, and Cleveland Heights, Ohio, received high rankings because of their low infant mortality rates, spacious, modern homes,

\footnotetext{
${ }^{4}$ See Kenneth L. Kusmer, A Ghetto Takes Shape: Black Cleveland, 1870-1930 (Urbana, I.L.: University of Illinois Press, 1976) and Joe William Trotter, Jr., Black Milwaukee: The Making of an Industrial Proletariat, 1915-194 (Urbana, I.L.: University of Illinois Press, Second Edition, 2007).

${ }^{5}$ Darlene Clark Hine, "Black Professionals and Race Consciousness: Origins of the Civil Rights Movement, 1890-1950," The Journal of American History, Vol. 89, No. 4 (March 2003), pp. 1279-1294.

${ }^{6}$ For two pioneering studies that provide a national history of African American suburbanization, see Leslie Wilson, Dark Spaces: An Account of Afro-American Suburbanization, 1890-1950 (PhD Diss.: City University of New York, 1992) and Andrew Wiese, Places of Their Own: African Americans and Suburbanization in the Twentieth Century (Chicago: University of Chicago Press, 2004). For two local studies of early black suburbanization, see Sherman Beverly, Jr., The Emergence of Black Political Power in Evanston: The Public Career of Edwin B. Jourdain, Jr., 1931-1947 (Evanston, I.L.L.: Northwestern University, PhD Diss., 1973) and Kevin Barry Leonard, Paternalism and the Rise of a Black Community in Evanston, Illinois: 1870-1930 (Evanston, I.L.: Northwestern University, MA Thesis, 1982).

${ }^{7}$ Walter Greason, From Village to Suburb: Race Politics and Economics in Monmouth County, NJ 18901990 (PhD Diss.: Temple University, 2004); Valerie Johnson, Black Power in the Suburbs: The Myth or Reality of African American Suburban Political Incorporation (Albany, N.Y..: State University of New York Press, 2002); Robert W. Lake. The New Suburbanites: Race and Housing in the Suburbs (New Brunswick, N.J: The Center for Urban Policy Research, Rutgers University, 1981); Steven Gregory, Black Corona: Race and the Politics of Place in an Urban Community(Princeton, N.J.: Princeton University Press, 1998); Karyn L. Lacy, Blue-Chip Black: Race, Class, and Status in the New Black Middle Class (Berkeley, C.A.: University of California Press, 2007); and Bruce Haynes, Red Lines, Black Spaces: The Politics of Race and Space in a Black Middle-Class Suburb (New Haven, C.T.: Yale University Press, 2001).
} 
the high degree of educational attainment among residents, and lack of extreme poverty, crime, and disease. $^{8}$

While it is not surprising that affluent white communities such as Glendale fared well in Thorndike's rankings, racially diverse service suburbs such as Montclair, Pasadena, and Evanston were also among this group. The presence of a significant Black population who worked primarily as private household workers characterizes these communities. Service suburbs were thus pivotal to the formation of racial ideologies and politics in metropolitan regions in the Northeast and Midwest during the early twentieth century, yet most case studies of racial politics in service suburbs focuses on struggles over school segregation

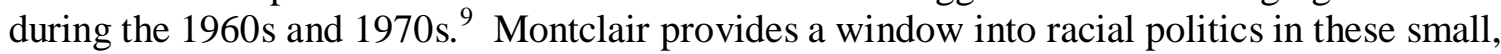
diverse communities during the interwar period.

Additionally, suburbanization and race are central to New Jersey history, yet few historians have examined suburban racial politics in New Jersey. Strikingly for the nation's most suburban state, historians have focused on the urban or rural experiences of black residents. ${ }^{10}$ Moreover, most studies of Black suburbanization focus on the post Civil Rights Era migration of middle-class blacks from Newark to surrounding suburbs. ${ }^{11}$

Montclair and other service suburbs were formative spaces for New Jersey's racial politics. African Americans formed a higher percentage of the population in service suburbs, including Montclair, than Newark and other cities during the interwar period. ${ }^{12}$

\footnotetext{
${ }^{8}$ E.L. Thorndike, Your City (New York: Harcourt, Brace, and Company, 1939).

${ }^{9}$ For instance, see Marian J. Morton, "The Suburban Ideal and Suburban Realities: Cleveland Heights, Ohio, 1860-2001, Journal of Urban History 2002 (28), pp. 671-698; Juliet Saltman, Open Housing: Dynamics of a Social Movement (New York: Praeger Publishers, 1978); Michael E. James, The Conspiracy of the Good: Civil Rights and the Struggle For Community in Two American Cities, 1875-2000 (New York: Peter Lang Press, 2005); B. Elisa Carol Diller, The Broken Mirror: Reflections in Narcissism, Mimesis and Racism in Plainfield, N.J. (PhD Diss.: Princeton Theology Seminary, Princeton, N.J., 1996); and W. Dennis Keating, The Suburban Racial Dilemma: Housing and Neighborhoods (Philadelphia: Temple University Press, 1994).

${ }^{10}$ See Giles R. Wright. Afro-Americans in New Jersey: A Short History (Trenton, N.J: New Jersey Historical Commission, Department of State, 1988); Kevin Mumford, Newark: A History of Race, Rights, and Riots in America (New York: New York University Press, 2007); and Komozi Woodward, A Nation within a Nation: Amiri Baraka (LeRoi Jones) and Black Power Politics (Chapel Hill, N.C.: University of North Carolina Press, 1999).

${ }^{11}$ See Lizabeth Cohen, Consumer's Republic: The Politics of Mass Consumption in Postwar America (New York: Knopf Press, 2003); Lake, New Suburbanites, Greason, From Village to Suburb; David L. Kirp, Our Town: Race, Housing, and the Soul of Suburbia (New Brunswick, N.J.: Rutgers University Press, 1995); and Michael Birkner, A Country Place no More: The Transformation of Bergenfield, New Jersey, 18941994 (Rutherford, N.J.: Fairleigh Dickinson Press, 1994).

${ }^{12}$ In the 1920 US Census, 11.5 percent of Montclair's population was African American, 4.7 percent of East Orange's 4.7, 10.9 percent of the Oranges', 8.8 percent of Plainfield's, and 7.8 percent of Englewood's. In 1930, African-Americans composed 4.7 percent of East Orange's population, 14.7 percent of Englewood's, 14.2 percent of Orange City's, 10.6 percent of Plainfield's, and 13.6 percent of Montclair's. By 1940, African-Americans formed 8.6 percent of East Orange's population, 15.8 percent of Englewood's, 17 percent of Montclair's, 15.7 percent of Orange City's, and 12.2 percent of Plainfield's. 1930 and 1940 United States Census Data. Untied States Government Publication. Washington, D.C. In sharp contrast, in 1920 Blacks formed only 2.1 percent of the population in Elizabeth, .3 percent in Hoboken, 2.7 percent in Jersey City, 4.1 percent in Newark, and 1.1 percent in Paterson. By 1940, Blacks were .5 percent of Hoboken's population, 4.9 percent of Elizabeth's, 4.6 percent of Jersey City's, 11.6
} 
Montclair's African American community's emphasis on economic and educational achievement during the interwar period differentiates racial politics from rural and urban places. ${ }^{13}$ African Americans migrated to Montclair because of the availability of domestic service work, the semi-rural environment, and the promise of freedom from the racial violence that plagued the South. ${ }^{14}$ Although the service sector jobs available in Montclair were among the best-paid positions open to black residents in the region, white residents used the economic dependence of African Americans to politically, socially, and geographically contain black residents. African Americans however, eagerly pursued educational and economic opportunities that promised to end their economic dependence on the white community well as the social and political implications it engendered. By 1950, Montclair's black community had evolved from a working-class community of service workers into an economically diverse community that included a significant Black professional class.

This paper argues that the Black community's economic and educational advancement was part of their struggle for equal access to jobs, housing, public spaces, and civic life in Montclair. The first European settlers arrived in 1666 and built a farming village inhabited by only a few thousand people for almost 200 years. In 1856, this changed after the first rail link between Newark, New Jersey's largest city, and West Bloomfield, the town adjacent to Montclair, opened. When Montclair incorporated in 1895, it was a residential suburb with almost 7,500 residents. Montclair continued to develop rapidly until the Great Depression. In 1923, for example, Montclair's government issued 1,175 permits for residential and commercial construction projects worth more than $\$ 7$ million. ${ }^{15}$ Between 1900 and 1920, the population grew almost 400 percent to 28,819 residents. ${ }^{16}$ Montclair had emerged as New Jersey's most desirable residential suburb. Colloquially known as "the millionaire belt," Montclair was the third wealthiest community per capita in the entire country in $1922 .{ }^{17}$

During the interwar period Montclair was divided between white middle and upper-class women and children who remained in the community and seldom worked, white middle and upper-class professional men who commuted to Newark and New York City, local proprietors who were usually middle-class white men, a working-class Italian enclave who worked in the construction trade, and the Black community who mostly held service sector positions in Montclair and other nearby suburbs. In 1920, African Americans comprised approximately 12 percent of Montclair's residents. By 1930, this number had increased to15

percent of Newark's, and 3.3 percent of Paterson's. 1920, 1930, and 1940 United States Census Data. United States Government Publication. Washington, D.C.

${ }^{13}$ Earl Lewis, In Their Own Interests: Race, Class, and Power in Twentieth-Century Norfolk, Virginia (Berkeley, C.A.: University of California Press, Berkeley, 1991). Lewis argues that African American residents of Norfolk developed autonomous institutions, cultural practices, family ties, and neighborhood pride as a strategy of resistance. He finds that blacks valued economic autonomy and community ties more than economic advancement.

${ }^{14}$ See Wiese, Places of Their Own, chapter 3 and Wilson, Dark Spaces.

${ }^{15}$ Montclair Chapter, New Jersey Society of the Sons of the American Revolution. The Story of

Montclair: Its People in Peace and War Times. (Montclair, N.J.: The Montclair Chapter of the new Jersey Society of the Sons of the American Revolution, 1930).

${ }^{16}$ Montclair League of Women Voters. Know Your Town: A Survey of Montclair, New Jersey.

(Montclair, N.J.: League of Women's Voters of Montclair, 1947).

${ }^{17}$ Montclair had an assessed property valuation of $\$ 60,000,000$ in 1922. "In the Eyes of Contemporaries."

Montclair Then and Now. Unpublished Manuscript. Montclair Historical Society. Montclair, New Jersey. 
percent or almost 6,300 of Montclair's 42,107 residents. ${ }^{18}$ Domestic service was the economic lifeline for African Americans during the interwar period. ${ }^{19}$ According to the New Jersey Conference of Social Work's 1935 on the Black community in Montclair, approximately 90 percent of Blacks employed in Montclair worked as domestic servants. ${ }^{20}$

In sharp contrast to the working-class status of most Black residents, most white men worked in well paid white collar occupations such as managers and officials, the largest single occupational category in $1930 .^{21}$ Although most married white women and affluent single young women did not hold paid positions, some white single women who lived independently from their families held clerical and white-collar positions as clerks, teachers, and bookkeepers. ${ }^{22}$

While most white residential suburbs attempted to prevent black migration during the interwar period, Montclair's upper-class white residents recruited African Americans for service sector positions as cooks, maids, chauffeurs, nurses, gardeners, and butlers.

In the Antebellum South, the economic relationship between white slave owners and black slaves created a fragile bridge that, according to Eugene D. Genovese, "linked individuals to their oppressors who function as a direct providers and protector to each individual as well as to the community as a whole.",23

In Montclair, domestic service similarly created a complex, hierarchal relationship predicated on the Black community's dependence on white residents. White residents, for instance, often attempted to help African Americans, but excluded them from civic leadership. Jane and Maxwell Barus, for instance, employed a live-in maid in their spacious home. Like

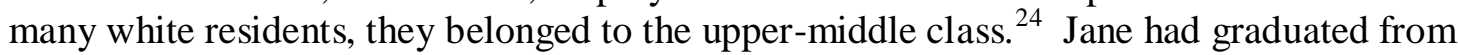
Wellesley College, arguably the finest college open to women at the time, and Maxwell was a partner at a well-known New York City law firm. ${ }^{25}$ While Maxwell commuted to New York City, Jane supervised Black women as a member of African American Montclair

\footnotetext{
181920 and 1930 US Census. US Census Bureau.

${ }^{19}$ Fourteenth Census of the United States. Volume IV. Occupations. (Washington, D.C.: Bureau of the Census, 1920), pp. 292-3.

${ }^{20}$ New Jersey Conference of Social Work, The Negro in Montclair (Newark, N.J.: New Jersey Conference of Social Work, 1935).

${ }^{21}$ Ibid, pp. 293. Fourteenth Census of the United States. Volume IV. Occupations. (Washington, D.C.: Bureau of the Census, 1920), pp. 292-3. In 1920, 384 out of 4,525 employed men worked as salesmen, 352 as bankers, 433 as retail dealers, 272 as technical engineers, and 150 as lawyers. In 1920, 234 men worked personal servants and an additional 70 as janitors. Domestic service employed 1,468 women as servants, 172 as nurses, and 189 as private laundresses. An additional 558 women worked as clerks, 252 as teachers, 382 as retail clerks, and 293 as bookkeepers.

22 Fourteenth Census of the United States, Volume IV. Occupations (Washington, D.C.: Bureau of the Census, 1920), pp. 292-3.

23 Eugene D. Genovese, Roll, Jordan, Roll: The World the Slaves Made (New York: Vintage Books, 1972), pp. 4-5.

24 "Mrs. Maxwell Barus, Fifty Year Resident." Montclair Times. August 17, 1977. 1920 United States Census Data. From Ancestry.com. United States Government Publication. Washington, D.C. Only Princeton had more residents listed in New Jersey's social register New Jersey Social Register. (Newark, N.J.: New Jersey Social Register, 1927). Newark Evening News Morgue File. Newark Public Library. Newark, New Jersey. Biographical File. Mrs. Maxwell Barus.

25 "Mrs. Maxwell Barus, Fifty Year Resident." Montclair Times. August 17, 1977.
} 
YWCA's white advisory board. ${ }^{26}$ Jane and the other white affluent women insisted that Black women needed their supervision. During the 1920s, these women advisory board rebuffed the national YWCA's repeated attempts to convince them to create a white branch in Montclair, insisting that the African American branch required their full attention. In their 1932 report to the national branch, the white women on the advisory board declared that, "there is not very much developed leadership among Negro women and the advisory board performs a great service." 27

Although the white community refused to view Black residents as equal citizens and civic leaders, in an era of mass migration, southern African Americans moved to Montclair because of the availability of well-aid service sector jobs and refused to accept their unequal status. The Townswomen of Montclair, Black women's club, described the migrants in their community history published in 1952 as, "young, vigorous, intelligent Negroes who sought to improve their lot by working in the North. Their relatives and friends had found jobs for them in the homes of the rich." ${ }^{28}$ Excluded from most skilled blue-collar and white-collar jobs in the Northeast and Midwest, service sector positions as chauffeurs and gardeners were among the highest-paid positions open to Black men other than professional employment until a massive labor shortage emerged during the Second World War. ${ }^{29}$ Black migrants actively sought out jobs that offered higher wages and greater autonomy. Indeed, many moved to Montclair because they recognized that the town's wealth meant higher wages for service positions. ${ }^{30}$ Lillian Connor earned $\$ 8$ a week in her first job as a domestic servant after she migrated to Montclair from Virginia. After working for there for two years, she located a job that paid $\$ 9$ a week in Caldwell, another affluent white resident adjacent to Montclair. One year later she landed a job in Montclair that paid \$11 a week and then a year later a job in Montclair that paid \$13 a week. Connor's pay increased 63\% because she actively sought higher wages. ${ }^{31}$ Connor also sought autonomy and lived with her cousin and aunt rather than with her employers while working as a domestic.

African Americans refused to allow their occupation to define their identity. Carrie Allen McCray, Black resident, recalled that domestic servants socialized at the Montclair YWCA, which was an African American branch, on their day off and were active members of Union Baptist Church. ${ }^{32}$ Lillian Connor, for example, joined Union Baptist Church, the Montclair YWCA and Montclair NAACP at the age of 14 and remained a lifelong member of all three organizations. ${ }^{33}$ Even though domestic servants had a multi-faceted identity, their economic

26 "Mrs. Maxwell Barus, Fifty Year Resident." Montclair Times. August 17, 1977. "Find Wings for the Work of Jailbirds." Newark Evening News. July 30, 1961.

${ }^{27}$ Sophia Smith Collection, Smith College, Northampton, MA. YWCA of the USA Records, 1860-2002, MS 324, Reel 190. June 24, 1932 Report, National YWCA.

${ }^{28}$ Townswomen of Montclair, Our Town. Montclair Historical Society, Montclair, New Jersey.

${ }^{29}$ Elizabeth Clark-Lewis, Living In, Living Out: African American Domestics in Washington, DC

(Washington, D.C.: Smithsonian Press, 1994).

${ }^{30}$ Clark-Lewis, Living In, Living Out.

${ }^{31}$ Lillian Margaret Connor Interview. Interviewed by Elizabeth Shepard, November 10, 2000. Montclair Historical Society. Montclair, New Jersey.

${ }^{32}$ Carrie Allen McCray, Freedom's Child: The Life of a Confederate General's Black Daughter (Chapel Hill, N.C.: Algonquin Books of Chapel Hill, 1998).

${ }^{33}$ Lillian Margaret Connor Interview. Interviewed by Elizabeth Shepard, November 10, 2000. Montclair Historical Society. Montclair, New Jersey. 
relationship with the white community impacted public life. Montclair's white residents leveraged their economic power to create a racial hierarchy predicated on the economic, social, political, and geographic containment and subordination of the Black community. ${ }^{34}$

White residents largely ignored gradual the emergence of an economically and socially independent black community during the 1920s and 1930sand attempted to contain and subordinate African Americans. Because of African Americans' importance as service workers, white residents acknowledged that blacks were members of the community and no significant public efforts ever emerged to remove them from the larger community or violently exclude them from public spaces or local politics. In 1925, for instance, Mary Daly, a middle-class white girl, was kidnapped from her home and murdered. Witnesses initially blamed an unidentified Black man, yet white residents did not rush to jud gment or blame African Americans for the crime. Instead, they allowed the local courts and police to conduct a thorough investigation of the crime and eventually convict Harrison Noel, the son of a wealthy lawyer who lived in Montclair, for the offense.

Still, white residents used segregation to contain and subordinate African Americans. Although formal de jure segregation never existed, white residents used racial restrictions in housing deeds, racial covenants in all-white neighborhoods, racially gerrymandered school boundaries, option attendance areas that allowed white parents in heavily minority school districts to send their child to another school, and social customs to geographically confine and segregate African Americans. For example, the Montclair Board of Education gerrymandered school district lines in 1933 to segregate Black and Italian children into specific junior high and grammar schools. Frank Pickell, Montclair's superintendent, acknowledged the board of education's intent to segregate Black children, declaring that, "Negroes should be satisfied with arrangements for separating Negro school children...in the South Negroes had to take the crumbs and were glad to get them." ${ }^{35}$ Moreover, according to Elizabeth Yarborough, who attended the public schools, school officials "sometimes still treated us [African Americans] as though we are stupid, recommending nearly all black children for trade school." 36

Rather than use violence to contain and subordinate Black residents, white residents relied primarily on their economic power. Since the Black community's economic subordination affected all aspects of public life in Montclair, the emergence of an autonomous, economically vibrant Black community challenged the racial hierarchy. Among the key features of the Black community's implicit challenge to white supremacy was a fervently encouraged ethnic of social responsibility where middle-class Blacks encouraged workingclass domestic servants to adopted middle-class practices and values, attend college, and pursue white-collar and professional careers. ${ }^{37}$

\footnotetext{
${ }^{34}$ I employ broad definition of racial politics to include not only formal political organizations and mobilizations, but also what Robin D. G. Kelley calls the politics of everyday life. Robin D.G. Kelley, "We Are Not What We Seem: Rethinking Black Working-Class Opposition in Jim Crow South." The Journal of American History. 88 (1) June 1993, pp. 75-112.

${ }^{35}$ Montclair Board of Education Minutes. September 18, 1933. Montclair Board of Education. Montclair, New Jersey

${ }^{36}$ Elizabeth Yarborough and Gwenda Williams Interview. Interviewed by Elizabeth Sheppard. Montclair Historical Society. Montclair, New Jersey.

${ }^{37}$ Victoria Wolcott, Remaking Respectability: African American Women in Interwar Detroit (Chapel Hill, N.C.: University of North Carolina Press, 2003); Evelyn Brooks Higginbotham, Righteous Discontent: the
} 
Lillian Margaret Connor's advancement from working as a domestic servant to owning her own cosmetology business illustrates the tenacious economic ascent of black migrants. Born in 1917 to parents who worked as sharecroppers on a tobacco, wheat, and corn farm in Virginia, she arrived in Montclair in 1931 when she was only fourteen years old as part of a large migration of Virginian sharecroppers who fled physical violence, political repression, and economic exploitation in the South. ${ }^{38}$ To Connor, Montclair's wealth meant job opportunities. She initially worked as a domestic servant, but pursued economic advancement by attending evening classes at Central High School in Newark, recalling later that she "was looking for something that paid more."39 Although racial discrimination prevented her from obtaining employment outside of domestic service after she graduated, Connor continued to pursue educational opportunities. She obtained a degree in cosmetology from the Apex College of Beauty Culture in Newark and finally employment outside the service sector as a factory worker after a severe labor shortage during World War II opened these positions to African Americans. While working at the factory, she continued to strive for economic advancement and saved enough money to open her own cosmetology business after the war ended.

Far being unique, Connor's story is a snippet of many African American migrants' longstanding pursuit of economic opportunities. Many blacks worked as domestic servants during the interwar period, but sought economic advancement and many had gained whitecollar positions by 1940. Other African American migrants worked as domestic servants throughout their lives, yet still encouraged their children to enroll in higher education so they could obtain white-collar jobs. Charles Brown worked as the Tarish family's chauffer for over 29 years starting in the 1910s. ${ }^{40}$ Although his position was well-paid and the family even bequeathed $\$ 20,000$ to him for his "faithful" service, he urged his daughter to avoid the kind of dependence the Tarish family held over him. His daughter, Rhea, however, graduated from Montclair Teacher's College by 1939 and worked as a secondary school teacher, illustrating the intergenerational mobility of service workers into white-collar positions. $^{41}$

Elizabeth Yarborough's father also insisted she seek employment outside domestic service, refusing to place her in a position of economic dependence on Montclair's white community. Like Charles Brown, Elizabeth's father earned a relatively high wage as a butler, but was economically dependent on a white family. Although he allowed her to work, he barred her from accepting a position as a domestic servant. Indeed, she recalled that he once became enraged when she informed him that she washed diapers at her part-time job at the age of sixteen as a mother's helper, insisting that she find another position. He also refused to allow Elizabeth's white guidance counselor to place her in a vocational program at Glenfield Junior

Women's Movement in the Black Baptist Church, 1880-1920 (Cambridge, Mass.: Harvard University Press, 1993); and Kevin K. Gaines, Uplifting the Race: Black Leadership, Politics, and Culture in the Twentieth Century (Chapel Hill, N.C.: University of North Carolina Press, 1996).

${ }^{38}$ Lillian Margaret Connor Oral Interview with author. January 19, 2007.

${ }^{39}$ Lillian Margaret Connor Interview. Interviewed by Elizabeth Shepard, November 10, 2000. Montclair Historical Society. Montclair, New Jersey.

40 "Chauffeur Given Cash." New York Amsterdam News. Ma 27, 1939.

41 "Chauffeur Given Cash.” New York Amsterdam News. Ma 27, 1939. 1930 United States Census Data. 
High School. He rejected the idea that she should pursue a vocational position, insisting that she enrolled in classes that prepared her for college and ultimately a professional career. ${ }^{42}$

Clem and Edna Lewis also encouraged their children to pursue economic and educational opportunities despite their own lack of formal education. After the couple moved to Montclair from Virginia during the 1920s, Clem worked as an unskilled laborer. Their son, Aubrey, recalled "carrying 50-poud bags of coal on his back for two miles" because the family could not afford a modern heating system or hot water. ${ }^{43}$ Although both parents lacked even a high school education, they encouraged Aubrey to graduate from Montclair High School. A star football player, he earned a scholarship to Notre Dame University and later enjoyed a successful business career, becoming a vice president at Woolworth in $1973 .{ }^{44}$ Lewis' success allowed him to purchase a spacious mansion in Montclair that The New York Amsterdam News, an African American newspaper, described as including a, "sweeping reception hall where a grand staircase spiraled upward to the second floor." His mother, Mrs. Edna Lewis, illuminated pride in her son's ascent from his small childhood home. After she laid eyes on the house for the first time, she smiled and simply told him, 'I'm proud of you, Aubrey.",45

In addition to moving up the social ladder themselves, the economic ascent of black service workers also drew black professionals and entrepreneurs to Montclair The upwardly mobile black community could financially support black establishments. In 1922, for example, Doctor John Kenney, the personal physician of Booker T. Washington, fled the South in duress and settled in Montclair, reputedly because he could practice medicine in the area without encountering the white community's open hostility and the Black community could financially support his practice. In Newark, New Jersey, Kenney founded a modern 30-bed hospital for African Americans, a much needed community service since black patients and physicians were barred from most hospitals in northern New Jersey. The hospital flourished because black residents could afford to patronize it. Its success made Kenney a figure of national importance and he co-founded the National Medical Association, a black professional medical association after white doctors refused to admit black doctors into the American Medical Association. ${ }^{46}$ Kenney built on the hospital's success by opening his own medical practice in Montclair in 1939. His practice thrived in Montclair because of the black community's relative affluence and economic mobility.

The economic mobility of Montclair's black community also attracted to Drs. George E. Bell and Ferdinand D. Williams to establish medical practices that served black residents. After living in Louisville, Kentucky and Washington, DC Bell moved to Montclair during the 1920s and established a thriving medical practice. Like Kenney, he became was a national leader among black doctors and led the New Jersey State Medical Society, a state branch of the National Medical Association. ${ }^{47}$ Similarly, Ferdinand Williams moved to Montclair and opened a dental client that served black residents after graduating from the Howard

\footnotetext{
42 Elizabeth Yarborough and Gwenda Williams Interview. Interviewed by Elizabeth Sheppard. Montclair Historical Society. Montclair, New Jersey.

431930 United States Census. US Government Publication. From Ancestory.com.

44 "What Makes This Dynamic Black Executive Run.” New York Amsterdam News. August 18, 1973.

45 Ibid.

46 "Death Ends Colorful Medical Career of Dr. John Kenney." Atlanta Daily World. February 2, 1950.

47 “Noted Jersey Doctor Dies.” New York Amsterdam News. December 28, 1940.
} 
University School of Dentistry in $1925 .^{48}$ The ability of Kenney, Williams, and Bell to establish financially successful medical practices suggests that the economic mobility of black service workers fueled the growth of Montclair's black professional class.

Black lawyers also established successful professional practices in Montclair built on the economic mobility of black service workers. Mary and William Allen were among the national black elite. Mary had attended Hartshorne Memorial College in Virginia and William had graduated from the University of Michigan's Law School. William, however, found that practicing law in Lynchburg, Virginia was futile. African Americans could not afford to pay a lawyer and the area's all-white juries always ruled against black citizens regardless of the facts presented in the case. ${ }^{49}$ According to Mary's brother-in law, Johnny, urged the couple to move to Montclair in 1920, exclaiming that there was "more money in this town per square foot than any place in the country." service workers in Montclair thus served as a magnet for Black professionals such as William who established a thriving law practice in Newark.

Although class distinctions existed, domestic servants' adoption of middle-class norms and aspirations created a cohesive Black community built on the economic security. The social atmosphere among Montclair's domestic workers attracted Black businessmen as well as the economic stability working for affluent white residents offered. During the 1920s, a small black business district emerged in Montclair built on the receipts earned from black service workers that featured drugstores, beauty parlors, barbershops, dress shops, and other small businesses. ${ }^{51}$ African American service workers could afford to patronize these businesses because of their economic mobility and stability. Indeed, the economic security and stability of black Montclair was rare among black communities and supported small trades and retail shops. Local black businessmen formed a business league to encourage African Americans to patronize these black-owned businesses, claiming that, "in our midst may be found a group of [black] people who can supply or cater to their wants." 52

In addition to small retail and service businesses, African Americans also established two fledgling financial institutions during the late 1920s, the New Jersey Life Insurance Company and Peoples Finance Corporation that provided Black residents with life insurance policies, financial investments, and home loans. ${ }^{53}$ While Newark and other nearby Essex County suburbs' Black communities also participated in these ventures, Montclair's provided the impetus behind its establishment. ${ }^{54}$ These two companies were successful because the stability of services workers' wages made it possible for black residents to afford to purchase insurance and financial products. The Peoples Finance Corporation collapsed during the Great Depression along with the housing market, but most of Montclair's black businesses survived, illustrating the Black community's economic stability.

\footnotetext{
48 "Montclair Dentist Buried." New York Amsterdam News. April 25, 1964.

${ }^{49}$ Carrie Allen McCray, Freedom's Child: The Life of a Confederate General's Black Daughter (Chapel Hill, N.C.: Algonquin Books, 1998), pp. 123-29.

50 Ibid, pg. 136.

51 "Montclair, N.J." The Pittsburgh Courier. November 8, 1924.

52 "Jersey Business League Plans Exposition." The Chicago Defender. October 10, 1936.

53 "Life Insurance Co. is Formed in New Jersey." The Chicago Defender. January 26, 1924.

54 “Sells \$50,000 Worth of Stock." The Pittsburgh Courier. July 30, 1927.
} 
In addition to resisting their political, social, and geographic containment, African Americans used their economic mobility to develop autonomous social organizations that provided the black community with a civic voice. The creation of black churches was crucial to this process because these they functioned as social networks and programs under the African American community's leadership. The Townswomen of Montclair's published a history of the black community in 1950 in which they remarked that black service workers "were so ambitious to build their churches." 55 Illuminating the Black community's investment in their churches, St. Mark's Methodist Episcopal and Union Baptist Church both erected new buildings during the 1920s. Union Baptist used the autonomous space its expanded facilities provided to create childcare and children's programs that provided black-controlled alternatives to similar programs led by white Protestant churches. ${ }^{56}$

Black Catholics founded St. Peter Claver in 1931 as another autonomous space that allowed them to contest their subordination and containment within white institutions. Located only half a mile from Mount Carmel, an Italian ethnic parish, and a mile from Immaculate Conception, Montclair's oldest and only territorial parish, the Archdiocese of Newark organized the church as a mission project. After white Catholics at Immaculate Conception Church forced African Americans to sit behind a screen in the rear of church during Mass, African Americans protested the humiliating treatment and petitioned for their own parish. ${ }^{57}$ Although the Archdiocese created St. Peter Claver as a response to racial discrimination, African Americans displayed enormous pride in it and used it to deliver social resources to their community. The parish organized a free employment bureau during the Great Depression that provided jobs to over 150 African Americans each month. ${ }^{58}$ The bureau leveraged Black networks to secure employment rather than a similar job bureau operated by the white, middle-class Montclair Women's Club, reducing the black community's economic dependence on white residents.

Although African Americans sought autonomy, the complex nature of Montclair's racial politics meant that they often carved spaces of independence inside of white-controlled organizations. For example, affluent white female members of St. Luke's Episcopal Church established an African American YWCA in 1912 after hearing a church lecture about the importance of civic duty. ${ }^{59}$ They assumed a caretaking, advisory, and fundraising role throughout the 1920s and 1930s. When the branch purchased a permanent facility, African American women raised $\$ 4,000$ to furnish it, but the all-white advisory board convinced Israel Crane, a wealthy white resident, to donate his house to the association. This as well as

\footnotetext{
${ }^{55}$ The Townswomen. Our Town.

${ }^{56}$ Three Score Years: A Brief History of the Union Baptist Church, 1889-1914. "Union Baptist Church of Montclair Started in '87." New York Amsterdam News. July 15, 1939. "Montclair." New York Amsterdam News. September 28, 1927. I am indebted to Evelyn Brooks Higginbotham's pioneering study on black churchwomen. Righteous Discontent: The Women's Movement in the Black Baptist Church, 1880-1920. (Cambridge: Harvard University Press, 2006). Three Score Years: A Brief History of the Union Baptist Church, 1889-1914.

${ }^{57}$ Elizabeth Milliken, "St. Peter Claver: Race and Catholicism in the Formation of an African American Parish" New Jersey History vol. 117, n.3-4. Winter 1999, pg. 7. The founding of St. Peter Claver was part of a broader effort by the Archdiocese of Newark to found black mission parishes. See Ward, A Mission for Justice.

58 “Open Free Employment Bureau at Mission House.” Montclair Times. December 16, 1932.

${ }^{59}$ Sophia Smith Collection, Smith College, Northampton, MA. YWCA of the USA Records, 1860-2002, MS 324, Reel 190.
} 
white women's supervision of the branch's Black leaders reinforced a subordinate, helping relationship between white and Black residents.

Despite the existence of an all-white advisory board, African American women used the YWCA to develop Black girl's leadership skills. Hortense Ridley Tate, the branch's Black leader, had moved to Montclair from Kansas in 1921 to work at the YWCA. Her appropriation of space within the branch challenged Montclair's racial hierarchy. She placed a sign in front of the branch that read, "For Colored Girls and Women." 60 Tate also taught Black girls cultural pride by starting every meeting with the Black national anthem, "Lift Every Voice and Sing," organizing an annual exhibit for Negro History Week highlighting the contributions of well-known black figures to the nation, and taking them to meet poets, writers, and other well-known Black cultural figures such as Langston Hughes and James Weldon Johnson in nearby Harlem. Carrie Allen McCray, who participated in programs at the YWCA and whose mother, Mary Allen, served as a branch leader, recalled that, "the YWCA had a much deeper meaning for us colored girls. It was a safe gathering place, a nurturing place. We were barred from so many other things in those days and the YWCA was the young colored girls' haven from prejudice." 61 Since young African American women were barred from participating in extracurricular activities except for the Negro Spiritual Choir at Montclair High School, the town's only public high school, they used the autonomous space the YWCA provided to organize dances, led clubs, created sewing circles, and other recreational activities. Black women carved spaces of autonomy within the $\mathrm{Y}$ that they used to teach young black women leadership skills and cultural pride.

Building on the growing economic security and demographic growth of their community in the 1920s, Black residents started to demand equal access to public spaces and institutions. The Claridge Theatre, a movie theatre in Montclair, was informally segregated. The movie theatre's white management forced black patrons sit in the balcony, reserving the floor seats for white patrons. African Americans refused to accept this practice. On, March 7, 1928, Laura Stewart, a 31-year old Black service worker, sat in the downstairs section of the theatre. ${ }^{62}$ She refused to move to the balcony when a white usher requested that she move. The Montclair Police arrested her on charges of disorderly conduct. The Montclair NAACP pressured Montclair's Town Attorney, George Harris, to drop the charges against Stewart. ${ }^{63}$

Harris initially rebuffed the NAACP's request. Moreover, illuminating the complex nature of Montclair's racial politics, refused to acknowledge the racial overtones of Stewart's arrest yet admitted that black residents had previously experienced harassment from the local police. He cautioned that, "We [Montclair's town government] should move slowly in this manner and find the most equitable way out of the situation. We all know that white or colored people have suffered from the bad manners of certain policemen." ${ }^{64}$ Failing to allay the Black community's anger, the NAACP quickly organized a picket of the theatre. After the

\footnotetext{
${ }^{60}$ Biography of Hortense Ridley Tate.” Montclair Public Library. YWCA Collection. Montclair, New Jersey.

${ }^{61}$ Biography of Hortense Ridley Tate." Montclair Public Library. YWCA Collection. Montclair, New Jersey.

${ }^{62} 1920$ United States Census Data. United States Government Publication. From Ancestory.com.

${ }^{63}$ Carrie Allen McCray, Freedom's Child: The Life of a Confederate General's Black Daughter (Chapel Hill, N.C.: Algonquin Books, 1998), pp. 22-30.

64 "Montclair Citizens Protest Segregation in Theatres." Pittsburgh Courier. April 21, 1928.
} 
picket persisted for weeks, harming business, the theatre's management reversed their policy and allowed black patrons to sit in anywhere in the theatre. The boycott succeeded because Black residents leveraged autonomous organizations such as the NAACP to demand equal access to public spaces. Moreover, members of the Black professional class such as Mary Allen led the protest, suggesting that white residents could not as easily contain and subordinate an economically independent African American community.

Montclair's African American community also challenged racial segregation in the public schools during the 1920s and 1930s, seeking equal access to educational opportunities. The Montclair Board of Education gerrymandered school boundaries that ensure that most Black and Italian children attended segregated schools and implemented a vocational curriculum in these schools. ${ }^{65}$ African American professionals led the fight against racial discrimination in the public schools. School discrimination thwarted their social and economic aspirations by preventing their children from attending college and pursuing professional careers, ultimately limiting the Black community's employment options to service sector positions and perpetuating their economic dependence on the white community. The parents of three children enrolled in the local schools and college graduates, Mary and William Allen likely hoped that their children would attend college and were determined to ensure that Black children had access to a college preparatory education ${ }^{66}$

Initially Mary Allen demanded that the board of education recognize Black children's educational achievements on an equal basis, confronting the white community's attempts to treat Blacks as inferior members of the community. Although Black teenagers attended Montclair High School, the school's annual commencement exercises humiliated Black students. At graduation, white graduates entered first followed by black graduates, reinforcing African Americans' subordination. Mary Allen contested this practice in 1929, the year before her oldest daughter, Rosemary, graduated. ${ }^{67}$ She approached the school superintendent, Frank Pickell, and demanded that graduates walk in alphabetical order regardless of their race during commencement exercises. The superintendent initially rebuffed her request, but Allen persisted and filed a complaint with the Montclair Board of Education. The board of education acceded to her demand on this symbolic issue and overturned the practice. When Rosemary Allen graduated in the spring of 1930, she entered in alphabetical order, making her second of all students. ${ }^{68}$ Her entrance near the head of the class challenged African Americans' social subordination and containment.

Conflict erupted again in the fall of 1933 after the Montclair Board of Education instituted new school district lines that increased the segregation of Black and Italian students at Glenfield School. Freda Kenney, the wife of physician John Kenney, and Mary Allen again

\footnotetext{
${ }^{65}$ African American activists in the North frequently relied on extralegal methods such as school boycotts when fighting racial discrimination in the public schools because legislative and legal remedies failed to address de facto segregation in the North. Davison M. Douglas, Jim Crow Moves North: The Battle over Northern School Segregation, 1865-1954 (Cambridge: Cambridge University Press, 2005), pg. 7. Ibid, pp. 105-11. Montclair Board of Education Minutes. September 18, 1933. Montclair Board of Education. Montclair, New Jersey

${ }^{66}$ Ibid, pp. 105-11. Montclair Board of Education Minutes. September 18, 1933. Montclair Board of Education. Montclair, New Jersey

${ }^{68}$ YWCA Papers. Unsorted collection. Montclair Public Library. Montclair, New Jersey. "Alter Graduate March.” The New York Times. June 13, 1925.
} 
confronted the school board over the new school boundaries, believing it to be a thinly veiled attempt to create an all Italian and Black school. ${ }^{69}$ Freda complained that the new district lines sent her sixth-grade daughter to Glenfield instead of predominantly white Hillside Junior High. Kenney noted that all of the black children from her daughter's graduating fifth grade class at Nishuane now attended Glenfield while all of the white students attended Hillside. ${ }^{70}$ Other African American parents also viewed the transfers as discriminatory, and the local NAACP organized a boycott of the public schools at the beginning of the 1933 school year. At the same time, William Allen, a black lawyer, filed a complaint on behalf of Elizabeth Kenney and three other children with the Montclair Board of Education. ${ }^{71}$ The board of education dismissed the complaint, insisting that their actions did not amount to racial discrimination. ${ }^{72}$

Although the boycott failed to change the board of education's policy, African Americans filed an appeal with the New Jersey State Commission of Education. The State Commission, however, rejected the NAACP's appeal. Almost a year and half later they reaffirmed the Montclair Board of Education's redistricting plan, declaring that, "all the Montclair schools have the same teaching standards and all accommodate both Negro and white students" and they were "satisfied that there is no general policy to segregate colored children." 73 The New Jersey State Commission allowed the Montclair Board of Education to increase racial segregation in Montclair's schools.

Black parents such as Mary Allen and Freda Kenney objected to school segregation because it allowed the Montclair Board of Education to force black children to take a vocational rather than college preparatory curriculum. At a board of education meeting held in October of 1933, Allen reminded the school board that she and other African Americans had previously expressed concerns that the new district lines would increase school segregation by sending nearly all black children to Glenfield School. Glenfield, Allen charged, failed to offer a college preparatory curriculum. She complained that school's ninth grade curriculum included an exploratory course in the languages instead of ancient history, Latin, and French, while these subjects were required at predominantly white Hillside and Northeast Junior High Schools. ${ }^{74}$ This difference handicapped Glenfield's pupils because most colleges required French, ancient history, and Latin for admission and these courses were part of at Montclair High School's college preparatory curriculum. By excluding these subjects from Glenfield's curriculum, the board of education restricted the ability to attend of African American students to attend college.

While Mary Allen and other Black residents sought a college preparatory education for their children, the board of education claimed that black children benefited from Glenfield's vocational curriculum because most were not intellectually suited for college and, even if

\footnotetext{
${ }^{69}$ For a broader discussion on battles over school segregation in the Northeast during the 1930s and 1940s, see Douglas, Jim Crow Moves North and Thomas Sugrue, Sweet Land of Liberty: The Forgotten Struggle for Civil Rights in the North (New York: Random House Press, 2008), chapter 6.

70 "School Officials Under Fire for Jim Crow Rule." The Chicago Defender. May 5, 1934.

71 "School Districts Cause Objections." Montclair Times. September 15, 1933.

72 Montclair Board of Education Minutes. September 18, 1933. Montclair Board of Education. Montclair, New Jersey.

73 "School Bias Held Legal." The New York Amsterdam News. February 15, 1935.

${ }^{74}$ Montclair Board of Education Minutes. October 3, 1933. Montclair Board of Education. Montclair, New Jersey
} 
they were, could not obtain positions that required a college degree. ${ }^{75}$ Frank Pickell, the superintendent, acknowledged that the new district lines increased segregation, but dismissed the complaints of the black parents, maintaining that, "Negroes should be satisfied with arrangements for separating Negro school children...in the South Negroes had to take the crumbs and were glad to get them." "76 In Pickell's view, since black children received a better education in Montclair than they would have in the South, black parents should be satisfied with Glenfield's vocational program. Similarly, Richard Greene, president of the Montclair Board of Education, insisted that Glenfield provided African Americans with a more than adequate education, describing Glenfield as, "one of finest school buildings in Montclair." 77 He asserted that, "the agitation arises from a few leaders of colored people," blaming Black residents rather than the board of education for the conflict over school segregation. Green even asserted that black children "were being neglected and not getting attention" because their parents pulled them from the public schools and even threatened to take legal action against the boycott's leaders for putting their political goals ahead of their children's welfare. ${ }^{78}$ School segregation sparked a conflict between white and Black residents. Black residents saw college education as a path to social and economic advancement while white educators attempted to force black children to enroll in a vocational track at predominantly black Glenfield Junior High School. White residents sought to prevent them from obtaining white-collar and professional positions and created a racial hierarchy based on the civic, geographic, and social subordination and containment of African Americans.

By the end of the interwar period, Montclair's African American community had developed into an occupationally diverse group that included service sector workers as well as a vibrant black professional class and blue-collar workers. In 1940, only 385 male and 2,435 female residents worked in service sector positions compared with 967 men and 3,690 women in 1930. The economic diversification and upward mobility of African Americans continued and indeed accelerated into the 1940s and 1950s. By 1960, this number had declined to only 28 men and 896 women. ${ }^{79}$ African Americans had scaled the economic ladder and had obtained employment outside of the service sector.

Montclair also emerged as a magnet for wealthy African Americans after the Second World War because of the existence of the pre-war black professional class. Reflective of Montclair's desirability as a black professional community, Montclair throughout the postwar decades would be home to many of the state's black pioneers in professional and civic affairs.

\footnotetext{
${ }^{75}$ Similarly, Michael James and Charles Wollenerg find that in Pasadena, California, another interwar service suburb, upper-middle class Anglos separated Mexican students purportedly for the benefit of the Mexican children. James, Conspiracy of the Good and Charles Wollenberg, All Deliberate Speed: Segregation and Exclusion in California Schools, 1855-1975 (Berkeley: University of California Press, 1976).

${ }^{76}$ Montclair Board of Education Minutes. October 3, 1933. Montclair Board of Education. Montclair, New Jersey

${ }^{77}$ Montclair Board of Education Minutes. October 3, 1933. Montclair Board of Education. Montclair, New Jersey

${ }^{78}$ Montclair Board of Education Minutes. September 18, 1933. Montclair Board of Education. Montclair, New Jersey.

${ }^{79} 1940$ United States Census Data. Pg. 896. Table 33. United States Government Publication. Washington, D.C. In 1950, only 162 employed men and 1,571 employed women worked as household workers. 1950 United States Census Data. United States Government Publication. Table 35, pg. 30. Washington, D.C. Table 78. 1960 United States Census Data. 32-272. United States Census Bureau. Washington, D.C.
} 
In 1956, Barbara Ann Morris became the first woman hired in New Jersey as an assistant United States attorney, in 1953 Leila Garden became the first African American leader of a mixed race social welfare agency in New Jersey, and in 1949 Martha Belle became the first African American woman admitted to the New Jersey Bar. ${ }^{80}$ Just as it had before WWII, the economic mobility and social autonomy exemplified by these individuals challenged local whites' efforts to ... the containment and subordination of African Americans.

Despite black Montclair's growing social and economic autonomy, the history of domestic service still impacted race relations in the city. In 1943, Jane Rick, a social scientist who examined juvenile delinquency in Montclair, noted that legacy of domestic service generated a great deal of racial tension. She remarked that, "the race problem is dynamite because of the psychological tangle made up by impossible mixture of the old employer-servant relationship and a new feeling of self sufficiency [blacks experienced]." ${ }^{\prime 1}$ Similarly, Rhetta Artler, another social scientist, surmised in her 1956 study of Montclair that the town's employer-servant history "created tremendous social barriers between elite whites and the black community." ${ }^{22}$ White residents no longer economically controlled blacks, but many found it difficult to give up the effort to politically, socially, and geographically subordinate and contain them.

An economically more diverse black community had emerged in Montclair by the end of the interwar period although domestic service remained an important source of employment for women. White residents slowly adopted a more nuanced understanding of the identity and place of black residents. African Americans used their economic diversification to create spaces of autonomy, which they mobilized to demand equal access to education, public space, and other social resources. Moreover, since Montclair's racial hierarchy was centered on whites' economic control over African Americans, their economic diversification undermined racial barriers in the schools, theatres, and public spaces and organizations throughout town.

New Jersey and African American historians should be more attentive to the racial politics in interracial suburbs. The economic relationship between the white and Black communities created a complex racial hierarchy predicated on the white community's ability to subordinate and control African Americans that differentiates Montclair's racial politics from all-white suburbs or large cities. Moreover, interracial suburbs were formative to New Jersey's racial politics since Blacks formed a larger percent of these communities than large cities during the interwar period and the complex economic relationship that emerged during the interwar period influenced racial politics beyond the post WWII era. New Jersey and African American scholars should examine the Black community's response to racial discrimination in interracial service sectors in the North and Midwest to better understand how service sector jobs provided opportunities for economic advancement and how Blacks

\footnotetext{
80 “Rutgers’ Law Graduates Pass N.J. Bar Examination.” Atlanta Daily World. November 19, 1949. "Brilliant Negro Woman another First in Legal Fields" Atlanta Daily World. March 28, 1956. "Gets Top Post in N.J. Agency." The New York Amsterdam News. July 4, 1953.

${ }^{81}$ Janet Rink. Juvenile Delinquency in Montclair, New Jersey. (New York School of Social Work, Columbia University, 1943).

${ }^{82}$ Rhetta M. Arter. Exploring Montclair: An Action-Directed Exploratory Study of Human Relations in Montclair, New Jersey Sponsored by the Neighborhood Council of Montclair. (New York: The Center for Human Relations Studies, School of Education, New York University, 1956).
} 
leveraged these positions to demand create rights and create vibrant enclaves in the midst of affluent white communities. 